\title{
Response by the corpuscles of Stannius to hypotensive stimuli in three divergent ray-finned fishes (Amia calva, Anguilla rostrata, and Catastomus commersoni): cardiovascular and morphological changes
}

\author{
D.G. Butler, ${ }^{\mathrm{a}, \mathrm{b}, *}$ D.H. Zhang, ${ }^{\mathrm{a}}$ R. Villadiego, ${ }^{\mathrm{a}}$ G.Y. Oudit, ${ }^{\mathrm{a}, \mathrm{b}}$ \\ J.H. Youson, ${ }^{\mathrm{c}}$ and M.Z.A. Cadinouche ${ }^{\mathrm{a}}$ \\ ${ }^{a}$ Department of Zoology, University of Toronto, Toronto, Ont., Canada M5S $3 G 5$ \\ ${ }^{\mathrm{b}}$ Department of Physiology, Medical Sciences Building, University of Toronto, Toronto, Ont., Canada M5S 1 A8 \\ ${ }^{\mathrm{c}}$ Department of Anatomy and Cell Biology and Division of Life Sciences, University of Toronto at Scarborough, Scarborough, Ont., Canada M1C 1 A4
}

Accepted 17 January 2003

\begin{abstract}
In accordance with their vital role in cardiovascular physiology (Butler and Zhang, 2001) corpuscles of Stannius (CS) from two teleosts and an holostean species showed marked and consistent degranulation and exocytotic responses to hypotensive stimuli. In eels (Anguilla rostrata LeSueur) acute blood withdrawal (hypovolemic hypotension) was followed by a prompt decrease in cardiac output $(\mathrm{CO})$ and dorsal aortic pressure $\left(P_{\mathrm{DA}}\right)$, a compensatory tachycardic response and an increase in systemic vascular resistance $\left(R_{\mathrm{SYS}}\right)$. Isovolemic hypotension induced by papaverine i.v, led to a similar, but more prolonged, decrease in $P_{\mathrm{DA}}$ but the heart rate (HR) continued to accelerate, thereby counterbalancing the severe and persistent decrease in $R_{\text {SYs }}$. Both hypovolemic and isovolemic hypotension were followed by a significant depletion of cytoplasmic granules from eel CS even though plasma concentrations of $\mathrm{Ca}, \mathrm{Mg}, \mathrm{Na}^{+}$, and $\mathrm{K}^{+}$were normal. In an ancient holostean fish, the bowfin, Amia calva and a generalized teleost fish, Catastomus commersoni, the number of cytoplasmic granules decreased by $39 \%$ and $54 \%$, respectively, 120 min after the acute withdrawal of $8 \mathrm{ml} \mathrm{kg} \mathrm{bw}^{-1}$ of blood. These findings suggest that a primary role of the CS is to release cytoplasmic granules containing renin or isorenin into the blood circulation, in response to hypotension and/or hypovolemia.
\end{abstract}

(C) 2003 Elsevier Science (USA). All rights reserved.

Keywords: Corpuscles of Stannius; Renin; Granules; Cardiovascular; Calcium page heading: hypotension regulates corpuscles of Stannius

\section{Introduction}

The corpuscles of Stannius (CS) are enigmatic glands which vary in number and are usually embedded in the kidneys of holostean (Bhattacharyya et al., 1982; DeSmet, 1962; Garrett, 1942; Marra et al., 1992, 1994; Youson and Butler, 1976) and teleostean (Hirano, 1989; Stannius, 1839 for review) fishes. The CS contain from one to three cell types, two of which are loaded with secretory granules that, on first inspection, remind one of zymogen granules in the cytoplasm of pancreatic exocrine cells.

\footnotetext{
${ }^{*}$ Corresponding author.

E-mail address: dbutler@zoo.utoronto.ca (D.G. Butler).
}

Fontaine (1964) reported that removal of the corpuscles of Stannius (CSX), led to electrolyte imbalance in European freshwater eels (A. anguilla) including hypercalcemia, hypophosphatemia, hyperkalemia, and hyponatremia. Some or all of these changes in plasma and muscle electrolyte concentrations were observed subsequently in freshwater $A$. anguilla (Chan et al., 1967, 1969; Chester Jones et al., 1965; Kenyon et al., 1980), freshwater North American eels (A. rostrata) (Butler, 1969, 1993, 1999) and goldfish (Carassius auratus) (Ogawa, 1968) after CSX.

Chester Jones et al. (1966) found that CSX lowered dorsal aortic blood pressure in conscious A. anguilla and that CSX extracts increased dorsal aortic blood pressure in intact eels and carotid arterial blood pressure in anesthetized Sprague-Dawley rats. It was reported 
subsequently that CS extracts from three teleost species, when incubated with homologous plasma, yielded material that increased carotid arterial blood pressure in pentolinium-blocked rats (Sokabe et al., 1970). In addition, Takemoto et al. (1983) found that a major peptide, $\left[\mathrm{Asn}^{1}, \mathrm{Val}^{5}, \mathrm{Asn}^{9}\right]$-ANG I, and a minor peptide, $\left[\mathrm{Asp}^{1}, \mathrm{Val}^{5}, \mathrm{Asn}^{9}\right]$-ANG I, were generated by incubating CS extracts with homologous plasma from chum salmon (Oncorhynchus keta). Ultimately, [Asn ${ }^{1}, \mathrm{Val}^{5}$, $\left.\mathrm{His}^{9}\right]-$ ANG I was identified in incubates of CS from Lophius lutilon and homologous plasma. It was assumed that the angiotensin converting enzyme (ACE) known to be present in fish gills (Olson et al., 1989), converted this physiologically inert ANG I to hormonally active ANG II. Physiological doses of ANG II increased cardiac output and dorsal aortic blood pressure in freshwater $A$. rostrata (Oudit and Butler, 1995). Recently we have measured the cardiovascular events in freshwater $A$. rostrata following removal of the CS (Butler and Oudit, 1994, 1995). We have also measured the changes in dorsal aortic and caudal venous blood flows in responses to ANG's and to extracts of both CS and the posterior kidney (Butler and Zhang, 2001). We have concluded that the electrolyte disturbances which follow CSX, including hypercalcemia, are not due to the loss of a calcium regulating hormone (for review see Wagner, 1994) but are a consequence of changes in patterns of blood flow to ion transporting cells in the gill epithelia, and to the sites of ion fluxes through the integument (Butler and Oudit, 1994).

The present experiments are based on the hypothesis that the secretory granules in holostean and teleostean CS contain renin or isorenin that is secreted in response to a decrease in arterial blood pressure and/or hypovolemia. To test this hypothesis we measured CS granulation following partial exsanguination (blood withdrawal) in an holostean, the bowfin (A. calva), and two teleosts, the freshwater North American eel ( $A$. rostrata) and the white sucker (C. commersoni). We also measured CS granulation in eels following the induction of isovolemic hypotension with papaverine.

\section{Materials and methods}

\subsection{Animals}

Bowfins (Amia calva L.) of both sexes and weighing from 500 to $1000 \mathrm{~g}$ were netted in the Bay of Quinte (Hay Bay) in Lake Ontario. White suckers (C. commersoni L.) of both sexes and weighing from 400 to 1000 $\mathrm{g}$ were trap-netted in August during their spawning migrations from Lake Ontario into the Humber River near Toronto. Female North American eels (Anguilla rostrata LeSueur), weighing from 800 to $1200 \mathrm{~g}$, were netted in the St. Lawrence River near the city of Quebec by Pêcheries Gingras, and shipped by air to Toronto. Each of the three species were transported to the Department of Zoology Animal Facility and placed in holding tanks supplied with flowing, aerated, dechlorinated tap water $\left(11 \pm 1^{\circ} \mathrm{C}\right)$ and fed earth worms $a d$ libitum twice weekly. Experimental fish were selected at random and transferred to $12 \mathrm{~L}$ plexiglass observation tanks filled with dechlorinated, aerated, tap water 5-7 days prior to surgery. During the experimental period, fish were kept at $12 \pm 1^{\circ} \mathrm{C}$ under a $12 \mathrm{~L}: 12 \mathrm{D}$ light cycle and not fed.

\subsection{Experimental groups and protocols}

\subsubsection{Cardiovascular responses to hypovolemic and} isovolemic hypotension in freshwater eels

Ventral aortic blood flow (CO), heart rate (HR) and dorsal aortic pressure $P_{\mathrm{DA}}$ were measured continuously for $15 \mathrm{~min}$ before, and $2 \mathrm{~h}$ after, (a) the induction of hypovolemic hypotension by acute blood withdrawal $\left(8 \mathrm{ml} \mathrm{kg} \mathrm{bw}{ }^{-1} ; n=5\right)$ and (b) the induction of isovolemic hypotension by a caudal i.v. injection of papaverine hydrochloride (1-[(3,4 dimethyloxyphenyl) methyl]-6,7dimethoxyisoquinolone $\mathrm{HCl} ; 30 \mathrm{mg} \mathrm{ml}^{-1}$; Charles Frosst, Montreal, Canada) in $0.20 \mathrm{ml}$ of saline followed by a $0.15 \mathrm{ml}$ saline wash through.

\subsubsection{Serial time-related measurement of CS granulation} in freshwater eels $0,15,60$, and $120 \mathrm{~min}$ after the withdrawal of $8 \mathrm{ml} \mathrm{kg} \mathrm{bw}^{-1}$ of blood

CS were collected from one eel at each time.

\subsubsection{CS granulation in freshwater eels 120 min after the induction of hypovolemic hypotension}

(a) sham blood withdrawal where a \#23 gauge hypodermic needle was inserted into the caudal vein approximately $10 \mathrm{~cm}$ posterior to the cloacal opening $(n=5)$; (b) hypovolemic hypotension following the withdrawal of $8 \mathrm{ml} \mathrm{kg} \mathrm{bw}^{-1}$ of blood by caudal venipuncuture $(n=5)$. At the conclusion of the experiment, each eel was anesthetized in a $0.3 \%$ aqueous solution of MS 222. Blood was collected by caudal venipuncture and the CS were removed and fixed for electron microscopic examination.

\subsubsection{CS granulation in freshwater eels 120 min after the induction of isovolemic hypotension}

(a) sham drug injection wherein $0.25 \mathrm{ml}$ of $0.9 \%$ saline was injected via the indwelling venous catheter $(n=5)$, and (b) the induction of isovolemic hypotension with $10 \mathrm{mg} \mathrm{kg} \mathrm{bw}^{-1}$ of papaverine injected via the caudal vein catheter. At the conclusion of the experiment, each eel was anesthetized in $0.3 \%$ aqueous solution of MS 222. Blood was collected by caudal venipuncture and the CS were removed and fixed for microscopic examination. 
2.2.5. CS granulation in bowfins (A. calva) and white suckers (C. commersoni) $120 \mathrm{~min}$ after the induction of hypovolemic hypotension

Sham-withdrawal $(n=3)$ or acute withdrawal of $8 \mathrm{ml} \mathrm{kg} \mathrm{bw}^{-1}$ of blood $(n=3)$ by caudal venipuncture from bowfins and white suckers followed by anesthesia and the removal and fixation of the CS from each fish.

\subsection{Surgical preparation for experiments}

Eels were anesthetized in an aqueous solution $\left(3 \mathrm{gl}^{-1}\right)$ of MS222 (tricaine methanesulphonate; Sigma Chemical, St. Louis, MO, USA). The eel was then wrapped in, and supported by, a wet cotton towel. Blood catheters were placed in the lieno-mesenteric artery and pushed forward to the level of the dorsal aorta; also in the caudal vein about $5 \mathrm{~cm}$ anterior to the tip of the caudal fin. Finally a Doppler flow probe was placed over the ventral aorta just anterior to the Conus arteriosus.

\subsubsection{Insertion of vascular catheters}

Local anesthesia was induced by an i.m. injection of 2\% lidocaine hydrochloride (Xylocaine, Astra Pharmaceuticals, Montreal, Canada) and then a $3 \mathrm{~cm}$ lateral incision was made parallel to the lateral line and $5 \mathrm{~cm}$ anterior to the tip of the caudal fin. Muscles were retracted and bone and overlying connective tissue were dissected from the area to expose the caudal vein (and artery). Care was taken not to disturb the caudal heart. A $2 \mathrm{~cm}$ length of the vein was freed from surrounding tissue and then a heparin-filled (Hepalean, 1000 USP $\mathrm{U} \mathrm{ml}^{-1}$, Organon Teknika, Toronto, Canada) polyethylene catheter (Intramedic PE 10; i.d. $0.28 \mathrm{~mm}$; o.d. $0.61 \mathrm{~mm}$; Clay Adams, NJ, USA) was inserted, pushed forward for a distance of $4-6 \mathrm{~cm}$, and tied in place with size 5-0 surgical silk. The incision was then closed with 5-0 silk sutures. This catheter was used for intravenous injections of saline vehicle or papaverine. A left ventrolateral incision was made through the body wall to gain access to the three major arterial branches from the dorsal aorta. The smallest of these, the lieno-mesenteric artery, was freed of connective tissue and fitted occlusively with a heparinized catheter (Intramedic PE 50; i.d. $0.58 \mathrm{~mm}$; o.d. $0.97 \mathrm{~mm}$ ) for measurements of arterial blood pressure. As before, the catheter was tied into place and heat sealed at the tip; then the body wall was closed with size 3-0 stainless steel wire.

\subsubsection{Implantation of Doppler flow probes}

A $3 \mathrm{~cm}$ ventro-medial incision anterior to the operculum exposed the Conus arteriosus. The ventral aorta was located, then a $1.5-2 \mathrm{~cm}$ length was cleared of surrounding connective tissue. Care was taken in to avoid rupturing the pericardium. A $2.4 \mathrm{~mm}$ cuff-type Doppler flow probe (Titronics Medical Instruments, Iowa, USA; $20 \mathrm{MHz}$ silastic tubing) fit closely around the ventral aorta. Both ends of the cuff were circumscribed and tied with size 5-0 surgical silk to reduce movement. Muscle layers were drawn together to hold the probe in place and then the incision was sutured with size 5-0 stainless steel wire. The probes were assumed to provide a negligible resistance to blood flow. Ultrasound transmission gel (Aquasonic 100, Parker Laboratories, NJ, USA) was applied to the inner edge of the cuff in the region of the transducer to enhance acoustic coupling. Leads from the flow probes and the implanted vascular catheters were both fastened to the skin, in two or three places, with 3-0 silk. Operated eels were given an i.m. injection of $50 \mathrm{mg}$ of Ampicillin (Penbritin-500, Ayherst, Montreal, Canada) and returned to their experimental tanks which were covered with black plastic sheeting. Eels with implanted flow probes and catheters were monitored for at least 3-4 days postoperatively.

\subsection{Calibration of Doppler flow probes}

A careful in situ post mortem calibration of each flow probe was made to obtain absolute values for blood flow rates as described previously (Butler and Oudit, 1995). Briefly, each eel was euthanized with an overdose of sodium pentobarbital i.v. (Somnotol, MTC Pharmaceuticals, Cambridge, ON) and placed in a supine position. The heart was exposed and the $C$. arteriosus was catheterized with a PE 190, i.d. $1.19 \mathrm{~mm}$; o.d.1.7 mm; (Clay Adams, NJ, USA) for perfusion of the ventral aorta. An outflow catheter (PE 100) was then inserted into the ventral aorta, $1-2 \mathrm{~cm}$ anterior to the Doppler flow probe. Undiluted, heparinized eel blood was used to calibrate the probes of a range of flow rates corresponding to the physiological range of both flow and pressure (Harvard Apparatus Infusion Pump). There was a precise linear correlation between blood velocity and mean volume flow. Data were analyzed by linear regression analysis to provide calibration curves $(r>0.93)$.

\subsection{Protocol for measuring cardiovascular responses by freshwater eels to hypovolemic or isovolemic hypotension}

The ventral aortic flow probe was connected to a directional-pulsed Doppler flow meter (Model 545C-4, Iowa University Bioengineering, USA) and the responses recorded continuously with a two-pen chart recorder (Model RD-1201, Omega Engineering, Stamford, CT, USA). The initial range setting for each probe was chosen to produce the maximal flow responses and these did not change during the course of the experiments. Zero flows were established by adjusting the range function to the zero position (internal electronic zero). The blood pressure catheter was flushed with saline and connected to an R.P. 1500 pressure transducer (Narco Bio-Systems, Chicago, IL, USA) and a Linear 
Model 1200 single-pen recorder (Linear Instrument, Reno, NV, USA). The undamped frequency of the pressure measuring system was $30 \mathrm{~Hz}$ and the damping ratio was 0.1 . Zero pressure was adjusted to the level of the water surface and the pulse pressure was allowed to achieve stability. The system was calibrated against a static heparinized saline reservoir before and after each pressure measurement.

\subsection{Calculation of cardiovascular parameters}

Cardiovascular parameters were derived from the following equations:

(1) Stroke volume (SV; $\left.\mathrm{ml} \mathrm{kg}^{-1}\right)=$ cardiac output (CO; $\left.\mathrm{ml} \mathrm{min}^{-1} \mathrm{~kg}^{-1}\right) /\left(\mathrm{HR}\right.$; beats $\mathrm{min}^{-1}$ ).

(2) Mean dorsal aortic blood pressure $\left(P_{\mathrm{DA}} ; \mathrm{mm} \mathrm{Hg}\right.$ $=$ diastolic pressure +0.56 pulse pressure (see Oudit and Butler, 1995 for explanation).

(3) Systemic vascular resistance $\left(R_{\mathrm{SYS}} ;\left(\mathrm{mm} \mathrm{Hg}^{-1} \mathrm{~min}\right.\right.$ $\mathrm{kg})=\left(P_{\mathrm{DA}}\right) /(\mathrm{CO})$.

\subsection{Collection of corpuscles of Stannius and fixation}

Fish were anesthetized with a $0.3 \%$ aqueous solution of tricaine methanesulphonate (MS 222) and killed with a blow to the head. Then a longitudinal incision was made through the ventral body wall of the bowfins to expose the kidneys. The CS or "white bodies" were clearly visible along most of the length of the kidney (Youson et al., 1976). Each CS together with the surrounding kidney was flooded with ice-cold glutaraldehyde (ICG) buffered to $\mathrm{pH} 7.3$ with phosphate and fixed for $5 \mathrm{~min}$. CS were excised from the adjacent kidney tissue and placed individually, in separate $2 \mathrm{ml}$ glass vials containing additional ice-cold fixative for $2 \mathrm{~h}$. In $A$. rostrata, there are two white oval corpuscles, approximately $3 \mathrm{~mm}$ in diameter, which are embedded in the ventral surface of the posterior or functional kidney at the point where the right postcardinal vein leaves it. Both CS were transferred to the ICG fixative for $2 \mathrm{~min}$ then removed, cut into about four pieces, and placed in a vial of ICG for $2 \mathrm{~h}$. In C. commersoni, there is a single large corpuscle of Stannius located near the post dorsal surface of the functional kidney. As with A. calva, the area near the single corpuscle was flooded with ICG fixative for $5 \mathrm{~min}$. Then it was excised and cut into small pieces no larger than about $2 \mathrm{~mm}$ in diameter. Three or four of these small pieces were transferred to a vial containing ICG fixative for $2 \mathrm{~h}$.

\subsection{Post-fixation}

Pieces of CS in each vial were washed several times with phosphate buffer and post-fixed for $2 \mathrm{hr}$ in chilled $1 \% \mathrm{OsO}_{4}$ buffered to $\mathrm{pH} 7.3$ with phosphate followed by dehydration in a graded series of chilled ethanol, then propylene oxide and embedded in Spurr's resin. Ultrathin sections were cut at various levels through the tissue blocks using a diamond knife on a Reichert OM U3 ultra-microtome. The sections were mounted on copper grids, stained with uranyl acetate and lead citrate and examined using a Hitachi Model H-7110 Electron Microscope. An unbiased person selected randomly 20 plots (sections) of each CS from control and experimental animals. Representative photomicrographs of these control and experimental tissue samples were taken by the same, unbiased person, familiar with fine structure but not the nature of the study. All sections were viewed at a magnification of $3500 \times$. As noted above, sample areas $\left(500 \mu \mathrm{m}^{2}\right)$ were selected randomly and photographed. A rectangle measuring about $27.4 \times 21.4 \mathrm{~mm}$ (the plot) was drawn on a transparent acrylic sheet, then subdivided into nine subplots for ease of counting granules. This sheet was then placed over each photomicrograph to count the total number of granules within the plot. Granules of all sizes were counted. Twenty of these plot counts were used to determine the average number of granules per plot in one CS collected from each fish in the eel exsanguination experiment and the eel papaverine experiment. Only five plots were counted for each CS in the bowfin and sucker exsanguination experiments. The average number of

Table 1

Granulation of the corpuscles of Stannius in relation to plasma electrolyte concentrations and osmolality in freshwater eels 120 min after the acute withdrawal of $8 \mathrm{mlkg} \mathrm{kw}^{-1}$ of blood from the caudal vein or the i.v. injection of $10 \mathrm{mg} \mathrm{kg} \mathrm{bw}^{-1}$ of papaverine via the caudal vein catheter

\begin{tabular}{|c|c|c|c|c|c|c|c|}
\hline Group & $\begin{array}{l}\text { No. } \\
\text { of plots }\end{array}$ & $\begin{array}{l}\text { Granules } \\
\text { per plot }\end{array}$ & $\begin{array}{l}\mathrm{Na}^{+} \\
\left(\mathrm{mmoll}^{-1}\right)\end{array}$ & $\begin{array}{l}\mathrm{K}^{+} \\
\left(\mathrm{mmoll}^{-1}\right)\end{array}$ & $\begin{array}{l}\mathrm{Ca} \\
\left(\mathrm{mmoll}{ }^{-1}\right)\end{array}$ & $\begin{array}{l}\mathrm{Mg} \\
\left(\mathrm{mmoll}^{-1}\right)\end{array}$ & $\begin{array}{l}\text { Osmoles } \\
\left(\text { mosmol } \mathrm{kg} \mathrm{H}_{2} \mathrm{O}^{-1}\right)\end{array}$ \\
\hline Sham controls $(n=5)$ & 100 & $216 \pm 5.4$ & $150 \pm 2.4$ & $1.74 \pm 0.1$ & $2.34 \pm 0.16$ & $1.28 \pm 0.18$ & $297 \pm 7.3$ \\
\hline Blood withdrawal $(n=5)$ & 100 & $141 \pm 6.1^{*}$ & $148 \pm 2.8$ & $1.61 \pm 0.14$ & $2.27 \pm 0.14$ & $1.36 \pm 0.22$ & $298 \pm 6.7$ \\
\hline Vehicle-injected $(n=3)$ & 60 & $245 \pm 7.5$ & $149 \pm 1.8$ & $1.65 \pm 0.1$ & $2.21 \pm 0.11$ & $1.24 \pm 0.12$ & $293 \pm 6.2$ \\
\hline $\begin{array}{l}\text { Papaverine }\left(10 \mathrm{mg} \mathrm{kg} \mathrm{bw}^{-1}\right. \\
\text { i.v.; } n=3)\end{array}$ & 60 & $173 \pm 8.1^{*}$ & $147 \pm 2.6$ & $1.71 \pm 0.13$ & $2.24 \pm 0.15$ & $1.32 \pm 0.19$ & $294 \pm 8.0$ \\
\hline
\end{tabular}

\footnotetext{
Values are means \pm SEM.

${ }^{*} P<0.01$ compared with sham controls (venipuncture only) or vehicle injected controls using Student's $t$ test for the comparison of sample means. Between-group comparisons of mean number of granules per plot were significant $P<0.01$ using an ANOVA.
} 
Table 2

Granulation of bowfin and white sucker corpuscles of Stannius $120 \mathrm{~min}$ after the acute withdrawal of $8 \mathrm{mlkg} \mathrm{bw}^{-1}$ of blood from the caudal vein

\begin{tabular}{lllcl}
\hline Fish & $n$ & Group & Number of plots per group & Number of granules per plot \\
\hline Bowfin & 5 & Sham controls & 25 & $276 \pm 11.0$ \\
& 5 & Blood withdrawal & 25 & $169 \pm 15.9^{*}$ \\
White sucker & 5 & Sham controls & 25 & $371 \pm 20.9$ \\
& 5 & Blood withdrawal & 25 & $140 \pm 25.2^{*}$ \\
\hline
\end{tabular}

Values are grand means \pm SEM.

${ }^{*} P<0.01$ compared with sham controls (venipuncture only) using Students $t$ test. An ANOVA, based on granule counts for each fish, in each of the two treatment groups, showed that there was a statistically significant effect on granulation $(P<0.01)$.

granules per plot for each fish could then be compared or, alternatively, used to calculate the grand mean for each treatment group (see Tables 1 and 2).

\subsection{Data analysis}

\subsubsection{Cardiovascular data}

Data were analysed using a two-factor repeated measures analysis of variance (ANOVA) with a post hoc comparison of means using a Bonferroni test (Super ANOVA+ Abacus Concepts, SAS Institute, Cary, NC). Pair wise comparisons were made using Students $t$ test.

\subsubsection{Granule counts}

It was found that granule counts fitted neither a Normal nor Poisson distribution so data sets were log transformed to stabilize the variances before being assessed using a one-way ANOVA (SPSS software 2000) to delineate overall treatment effects. Student Neuman-Keuls test was used to compare means when the ANOVA indicated a significant treatment difference $(P<0.01)$. Mean granule counts for each fish CS were used to determine the grand mean. Values reported in the text, tables and figures are means \pm SEM. Differences were considered to be significant when $P<0.01$.

\subsection{Animal experimentation}

All of the experiments were reviewed and approved by the University of Toronto Animal Care Committee and fall within Animal Care guidelines set out by the Provincial and Federal Governments.

\section{Results}

\subsection{Effects of exsanguination and papaverine on cardio- vascular function and plasma electrolytes in A. rostrata}

Baseline cardiovascular parameters are similar to those previously observed in freshwater $A$. rostrata
(Butler and Oudit, 1995). Figs. 1 and 2 illustrate the impact of hypotension and hypovolemia $120 \mathrm{~min}$ after the withdrawal of $8 \mathrm{ml}$ blood $\mathrm{kg} \mathrm{bw}^{-1}$ or the i.v. injection of $10 \mathrm{mg} \mathrm{kg} \mathrm{bw}^{-1}$ of the vasorelaxant papaverine (isovolemic hypotension) on cardiovascular function.

Withdrawal of $8 \mathrm{ml} \mathrm{kg} \mathrm{bw}^{-1}$ of blood was followed by a prompt decrease in cardiac output (CO) from the baseline level of $16.2 \pm 1.3$ to $5.1 \pm 0.9 \mathrm{ml} \mathrm{min}^{-1} \mathrm{~kg}$ $\mathrm{bw}^{-1}$ within $5 \mathrm{~min}$ (Fig. 1A). During this time, heart rate (HR) increased sharply to counterbalance the depressed stroke volume and remained about 40\% higher than baseline (Fig. 1B). Even with this increased HR, CO increased relatively slowly because of the depressed stroke volume (blood loss) and never regained the preblood withdrawal rate (Fig. 1) This increase in HR was complimented by a rapid onset, and nearly parallel, increase in systemic vascular resistance $\left(R_{\mathrm{SYS}}\right)$ (Fig. 2B) which decreased but never reached the baseline level during the 120 min observation period. These cardiovascular responses brought the dorsal aortic pressure $\left(P_{\mathrm{DA}}\right)$ back to baseline about $60 \mathrm{~min}$ after the blood was withdrawn (Fig. 2A). Acute blood withdrawal had no measurable effect on eel plasma electrolyte or osmolal concentrations (Table 1).

An i.v. injection of $10 \mathrm{mg} \mathrm{kg} \mathrm{bw}^{-1}$ of papaverine was followed, within $5 \mathrm{~min}$, by a $70 \%$ decrease in HR (Fig. 1B) and a nearly equivalent increase $(100 \%)$ in stroke volume (SV). The CO returned to near baseline levels within $15 \mathrm{~min}$ after the injection of papaverine but, thereafter, increased to a level that was significantly (13\%) higher than baseline level by $45 \mathrm{~min}$ and 25\% higher after 120 min (Fig. 1A). This permanent increase in $\mathrm{CO}$ only partially offset the permanent loss of vasomotor tonus and nearly $50 \%$ decrease in $R_{\mathrm{SYS}}$. As a consequence, $P_{\mathrm{DA}}$ decreased by $60 \%$ within 10 min, was unchanged for a further $30 \mathrm{~min}$, then rose slowly but never reached the baseline again (Fig. 2A). Even though papaverine induced an isovolemic hypotension it continued for a much longer period (Fig. 2A). An i.v. injection of papaverine led to a sustained decrease in $\mathrm{CO}, P_{\mathrm{DA}}$ and $R_{\mathrm{SYS}}$ but these cardiovascular changes were not accompanied by any measurable changes in plasma electrolyte or osmolal concentrations. 



Fig. 1. Cardiac output (A, $\left.\mathrm{ml} \mathrm{kg} \mathrm{bw}^{-1} \mathrm{~min}^{-1}\right)$; heart rate (B, beats per minute) and stroke volume $\left(\mathrm{C}, \mathrm{ml} \mathrm{kg} \mathrm{bw}^{-1}\right)$ following blood withdrawal $\left(8 \mathrm{ml} \mathrm{kg} \mathrm{bw}^{-1}\right.$; closed circles; $\left.n=5\right)$ or an intravenous injection of papaverine $\left(10 \mathrm{mg} \mathrm{kg} \mathrm{bw}^{-1}\right.$; open circles; $\left.n=5\right)$. Time $=0$ refers to the point of acute blood withdrawal or papaverine injection. $P<0.01$ for both overall group and time effects. ${ }^{*} P<0.05$ compared with control value (time $=-5 \mathrm{~min})$.

\subsection{Histological data}

The CS of all three species under investigation possess lobules of principal epithelial cells with spherical nuclei, prominent, often parallel arrays of rough endoplasmic reticulum (RER), a conspicuous Golgi apparatus, and electron-dense secretory granules. Although it is mainly the distribution and number of secretory gran-
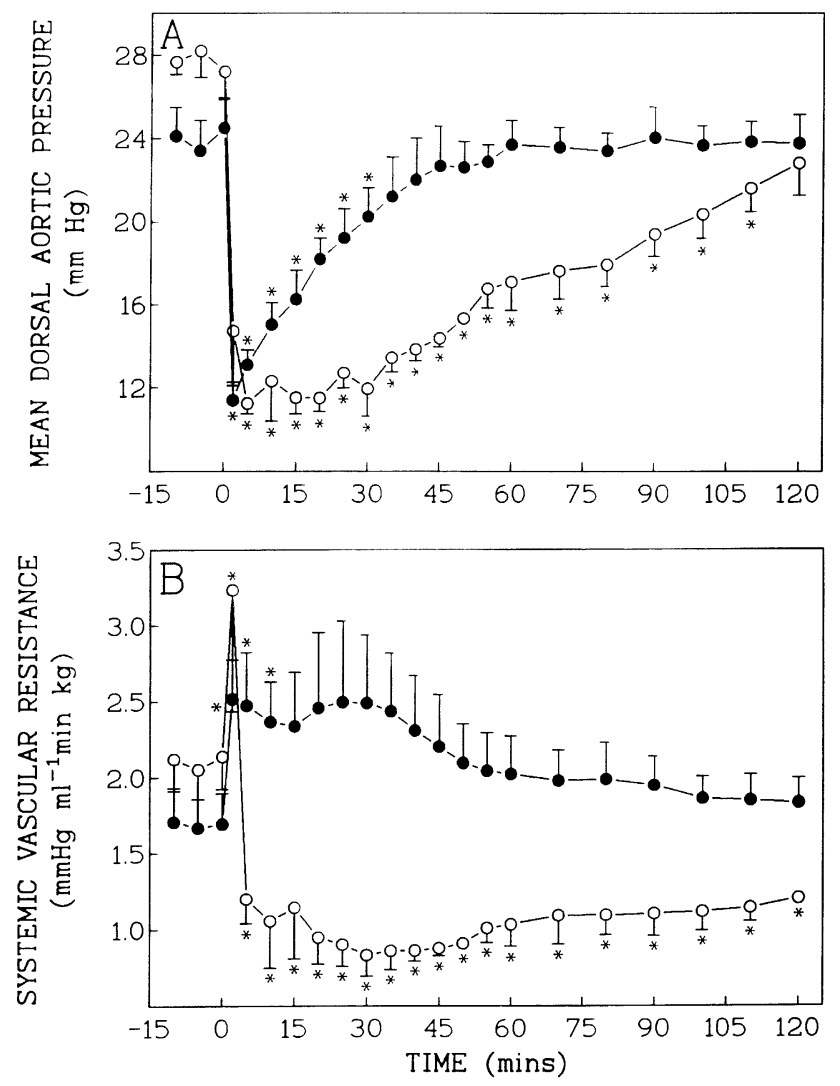

Fig. 2. Mean dorsal aortic blood pressure (A, $\mathrm{mm} \mathrm{Hg}$ ) and systemic vascular resistance $\left(\mathrm{B}, \mathrm{mm} \mathrm{Hg} \mathrm{ml} \mathrm{Hg}^{-1} \mathrm{~kg} \mathrm{w}^{-1}\right.$ ) following blood withdrawal $\left(8 \mathrm{ml} \mathrm{kg} \mathrm{bw}^{-1}\right.$; closed circles; $\left.n=5\right)$ or an intravenous injection of papaverine $\left(10 \mathrm{mg} \mathrm{kg} \mathrm{bw}^{-1}\right.$; open circles; $\left.n=5\right)$. Time $=0$ refers to the point of acute blood withdrawal or papaverine injection. $P<0.01$ for both overall group and time effects. ${ }^{*} P<0.05$ compared to control values $($ time $=-5 \mathrm{~min})$.

ules under consideration in the present study, there were noteworthy changes in the profile of the RER after exsanguination.

3.2.1. Serial time-related changes in granule content of cells of freshwater eel CS at $t=0,15,60$, and $120 \mathrm{~min}$ after the withdrawal of $8 \mathrm{ml} \mathrm{kg} \mathrm{bw}^{-1}$ of blood

Cells of the CS from the control eel were characterized by a cytoplasm with numerous electron-dense granules of variable diameter (Fig. 3a). The mean number was $297 \pm 14.7$ granules over the entire 20 plots from the same gland. The CS of an eel sampled $15 \mathrm{~min}$ after acute blood withdrawal showed a cytoplasm of principal cells that was greatly depleted of secretory granules and the cisternae of the RER were highly dilated (Fig. 3b). The overall mean granule count in this eel was lowered by $56 \%$ to $130 \pm 10.6$ compared with the eel observed at time $=0$. The mean granule count decreased to $107 \pm 9.3$ in the third eel, sampled $60 \mathrm{~min}$ after acute blood withdrawal. Fig. 3c shows that the cytoplasmic granules seemed to be of smaller diameter than those in the control group (compare Figs. 3a and c) 



Fig. 3. Serial time-related changes in eel CS granulation at: (a) time $=0$, (b) $15 \mathrm{~min}$, (c) $60 \mathrm{~min}$, and (d) 120 min after the acute withdrawal of $8 \mathrm{ml}$ blood kg bw${ }^{-1}$. The micrographs show a prominent loss of cytoplasmic granules and dilation of RER cisternae. Sections (e) and (f) are from eel CS 120 min after either a sham-blood withdrawal (e) or the acute withdrawal of $8 \mathrm{ml} \mathrm{blood} \mathrm{kg} \mathrm{bw}^{-1}$ (f). Note that the cells are degranulated following acute blood withdrawal but the sham resembles the control (a) above. $3500 \times$.

but no analysis of granule diameters was made. Also, in general, there was a dilation of cisternae of RER. Finally, 120 min after acute blood withdrawal the mean number of granules in 20 plots of the CS in the fourth eel was $97.7 \pm 9.8$. These observations imply that there is a temporal relationship between hypovolemic hypotension and the depletion of cytoplasmic granules from the CS.

\subsubsection{Cytoplasmic granules in the CS of freshwater eels} 120 min after sham or acute withdrawal of $8 \mathrm{ml} \mathrm{kg} \mathrm{bw}^{-1}$ of blood

In Fig. 3e there are about 228 granules in the CS sample plot from a single sham blood withdrawal eel. Moreover, the mean number of granules from 20 plots from each of the five sham-withdrawal eels was
$215 \pm 5.3$. Fig. $3 f$ illustrates a CS sample plot from an eel $120 \mathrm{~min}$ after the acute withdrawal of $8 \mathrm{ml} \mathrm{kg} \mathrm{bw}^{-1}$ of blood wherein there is nearly total degranulation and the RER cisternae are narrow. The response to acute blood withdrawal in the whole group of five eels was not as great insofar as the mean number of granules in a total of 20 plots from each of the five eels in this group was $141 \pm 6.1$ (Table 1). An ANOVA of the log transformed data for cytoplasmic granule counts showed that there was a statistically significant difference between the treatment groups $(P<0.001)$.

There were no changes in plasma electrolyte or osmolal concentrations (Table 1) $120 \mathrm{~min}$ after acute blood withdrawal which showed that granule depletion was not a consequence of a change in plasma $\mathrm{Ca}$ or other measured electrolytes. 
3.2.3. Granulation of CS in freshwater eels 120 min after the sham-injection of saline vehicle or the injection of $10 \mathrm{mg} \mathrm{kg} \mathrm{bw}^{-1}$ of papaverine

Comparisons were made of cells from eel CS $120 \mathrm{~min}$ after a sham-injection of saline vehicle $(n=3)$ or the injection of papaverine $\left(10 \mathrm{mg} \mathrm{kg} \mathrm{bw}^{-1}\right)(n=3)$ (Table 1). The granule count in the representative sham plot (Fig. 4a) is 248, whereas the mean for a total of 60 plots (20 for each of three eels) was $245 \pm 7.7$ (see Table 1). The granule count in the representative plot from a papaverine injected eel was 55 (Fig. 4b) with an average of $173 \pm 8.1$ granules per plot for 60 plots from three eels (Table 1). An ANOVA of the log-transformed data showed that there occurred a $29 \%$ depletion of granules in response to papaverine-induced isovolemic hypoten- sion was statistically significant $(P<0.001)$ (Table 1 ; see also Figs. 1 and 2 for cardiovascular changes in response to papaverine). Note that the induction of isovolemic hypotension was not accompanied by measurable changes in plasma electrolyte or osmolal concentrations (Table 1. There was no correlation between granule depletion and plasma $\mathrm{Ca}$ concentrations (Table 1).

\subsubsection{Granule count in CS from bowfin (A. calva) and} white sucker (C. commersoni) 120 min after the sham or acute withdrawal of $8 \mathrm{ml}$ blood $\mathrm{kg} \mathrm{bw}^{-1}$

(i) Bowfin. Figs. $4 \mathrm{c}$ and d are representative sections of bowfin CS taken 120 min after sham blood withdrawal and $120 \mathrm{~min}$ after the acute withdrawal of $8 \mathrm{ml} \mathrm{kg} \mathrm{bw}{ }^{-1}$ of blood. There is clear evidence of de-
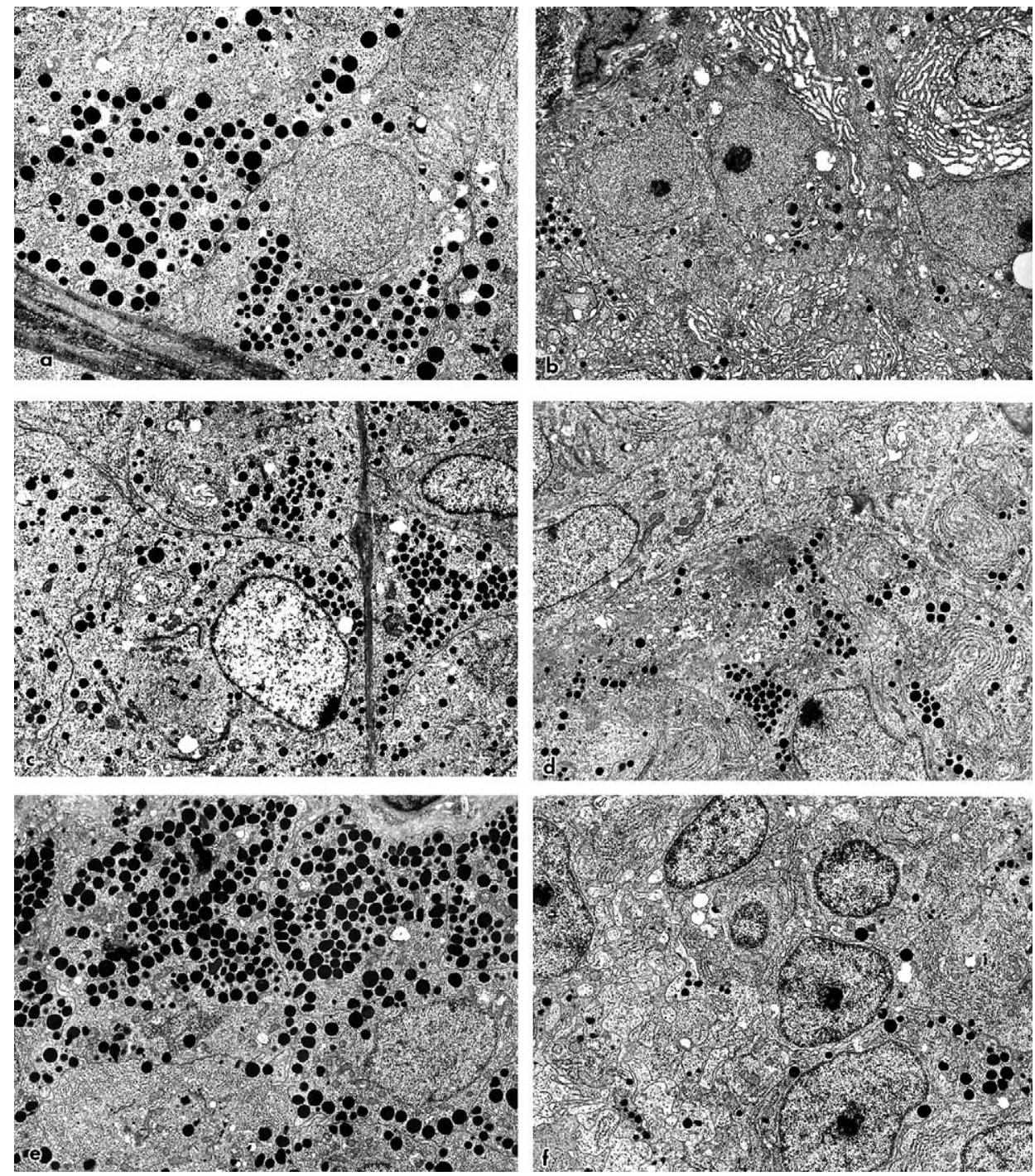

Fig. 4. Electron micrographs of cells from the CS of three teleost species showing granule depletion in response to isovolemic or hypovolemic hypotension. An eel CS sampled 120 min after a caudal i.v. injection of saline vehicle (a) is compared with CS sampled 120 min after a caudal i.v. injection of $10 \mathrm{mg}$ papaverine $\mathrm{kg} \mathrm{bw}^{-1}$ (isovolemic hypotension) (b). (c) Illustrates CS cells in a bowfin 120 min after the sham withdrawal of blood from the caudal vein bowfin and $120 \mathrm{~min}$ after the induction of hypovolemic hypotension by the acute withdrawal of $8 \mathrm{mlkg} \mathrm{kw}^{-1}$ of blood (d). Finally, (e) compares white sucker CS $120 \mathrm{~min}$ after sham blood withdrawal with CS after acute blood withdrawal $\left(8 \mathrm{ml} \mathrm{kg} \mathrm{bw}^{-1}\right),(\mathrm{f}) 3500 \times$. 
granulation in response to hypovolemic hypotension. In this group of sham-withdrawal bowfins the mean number of CS granules from 25 plots (five plots from each of five fish) was $272 \pm 7.8$, whereas the mean number of granules in 25 plots from five bowfins after acute blood withdrawal was $169 \pm 7.1$; this latter value is about $40 \%$ lower (Table 2).

An ANOVA using log-transformed data showed that there was a significant treatment effect $(P<0.001)$.

(ii) White sucker. Figs. $4 \mathrm{e}$ and $4 \mathrm{f}$ are representative profiles of cells of CS taken from one of five sham-blood withdrawal suckers and one of five suckers 120 min after the withdrawal of $8 \mathrm{ml}$ blood $\mathrm{kg} \mathrm{bw}^{-1}$. Visually, there is a marked decrease in granule number following acute blood withdrawal Fig. 4f. In the sham- withdrawal control suckers the mean number of granules for 25 plots (five plots for each of five suckers) was $372 \pm 12.2$, whereas in suckers from which $8 \mathrm{ml} \mathrm{kg} \mathrm{bw}^{-1}$ of blood had been withdrawn the mean number of granules was $146 \pm 9.9$. This amounted to a $61 \%$ decrease in granule content. An ANOVA using log- transformed data showed that there was a significant treatment effect $(P<0.01)$ (see Table 2).

\section{Discussion}

Recently, Butler and Zhang (2001) have shown that in conscious, free-swimming eels ( $A$. rostrata) both dorsal aortic and caudal venous blood flows increase in a dose-dependent manner following i.v. injections of $\left[\mathrm{Asp}^{1}, \mathrm{Val}^{5}\right]$ ANG II as low as $5 \mathrm{ng} \mathrm{kg} \mathrm{bw}{ }^{-1}$. Similar responses were observed following injections of extracts of corpuscles of Stannius (CS) which, in turn, were blocked by an injection of the angiotensin converting enzyme inhibitor, captopril. On the basis of this, and other eel experiments (Butler and Oudit, 1994, 1995; Oudit and Butler, 1995), it was concluded that the principal function of the CS is to release renin or a renin-like enzyme. Furthermore, it is believed that electrolyte changes after removal of the CS are not due to the loss of a specific calcium-regulating hormone but rather to changes in patterns of blood flow to ion-transporting cells in the gills, skin, gut and kidneys (Butler and Oudit, 1994). If our view is accurate, one may expect that the content of the secretory granules in the CS to be released in response to pressure/volume changes in much the same fashion as with the granular content of renal juxtaglomerular cells in mammals. In the present experiments we tested this CS-vascular relationship (renin hypothesis) by attempting to show if there is a depletion of secretory granules from eel CS after acute blood withdrawal or after an i.v. injection of the powerful vasodilator, papaverine. This relationship was also studied in two additional ray-finned fishes using the blood withdrawal paradigm.
Cardiovascular responses to hypovolemic hypotension are illustrated in Figs. 1 and 2. There was a 56\% decrease in $P_{\mathrm{DA}}$ within 2 min after acute blood withdrawal. The SV also dropped sharply due to blood loss and remained lower whilst the HR accelerated rapidly so that the $\mathrm{CO}$, initially depressed, rose gradually. The increased $\mathrm{CO}$ and increased peripheral vasoconstriction $\left(R_{\mathrm{SYS}}\right)$ gradually re-established the $P_{\mathrm{DA}}$ which had returned to baseline within about 45 min (Figs. 1 and 2). The CS responded to hypovolemic hypotension by releasing about $35 \%$ of the cytoplasmic granules within $120 \mathrm{~min}$ (Table 1). In addition, CS depletion was observed in 20 count plots for each of three single eels 15 , 60 , and 120 min compared with a control eel at time 0 . This additional observation tended to strengthen the evidence of a causal relationship between hypotension and granules release from the CS.

In bowfins (Marra et al., 1992) and white suckers (Marra et al., 1998) these secretory granules contain a protein that is immunoreactive to an antibody directed against "stanniocalcin" but the major secretory product within these granules may be renin, isorenin or some other catalytic protein associated with the renin-angiotensin system.

One may argue, that since CS granules contain the putative hypocalcemic hormone Stanniocalcin their depletion was simply a response to hypercalcemia or other changes in plasma (extracellular fluid) electrolyte concentrations (for review see Wagner, 1994). Table 1 shows that plasma $\mathrm{Ca}, \mathrm{Mg}, \mathrm{Na}^{+}, \mathrm{K}^{+}$and osmolal concentrations were unchanged after acute blood withdrawal so the release of granules was not $\mathrm{Ca}$-dependent.

Having examined the response by the CS to hypovolemic hypotension it was important to try to differentiate between a response to blood loss and a hypotension caused by drug-induced vasodilation. $\mathrm{Pa}-$ paverine was selected because it has been used successfully in eels (Tierney et al., 1995). The cardiovascular response to papaverine differed from the response to blood withdrawal (Figs. 1 and 2) insofar as there was an immediate drop in $P_{\mathrm{DA}}$ but the pressure remained at that level for about $30 \mathrm{~min}$ and then gradually returned to $82 \%$ of baseline after $120 \mathrm{~min}$. There was an early decrease in HR which was counterbalanced by an increase in SV but as time passed the SV returned to baseline and the HR continued to increase and therefore $\mathrm{CO}$ increased to compensate for the peripheral vasorelaxation. This and the early and continued decrease in peripheral vascular resistance held the $P_{\mathrm{DA}}$ down so that it never fully recovered until the end of the experiment (Figs. 1 and 2. This immediate and extended decrease in $P_{\mathrm{DA}}$ was correlated with a $30 \%$ decrease $(P<0.01)$ in eel CS granulation $120 \mathrm{~min}$ after the injection of papaverine (Table 1). Fig. 4a shows that there was about 248 cytoplasmic granules in a plot from a sham-injected eel whereas there were approximately 55 granules in a CS 
plot from a papaverine injected eel. Thus isovolemic hypotension led also to a response by eel CS. Our claim that papaverine-induced granule secretion represents the release of renin is indirectly supported by the observations of Tierney et al. (1995). They reported that the same dose of papaverine $\left(10 \mathrm{mg} \mathrm{kg} \mathrm{bw}^{-1}\right.$ i.v. was followed by a $240 \%$ increase in plasma ANG II in freshwater eels (A. anguilla) within $60 \mathrm{~min}$ after drug delivery. During acclimation to seawater the response to isovolemic hypotension was even greater. ANG II rose from a baseline of about $25 \mathrm{fmol} \mathrm{ml}^{-1}$ to $375 \mathrm{fmol} \mathrm{ml}^{-1}$ (14 fold) within 60 min after the same dose of papaverine. This papaverine experiment was repeated in rainbow trout (O. mykiss) acclimated to freshwater (Bernier et al., 1999). In this latter study, plasma ANG II increased 32fold from a baseline concentration of $125 \pm 12 \mathrm{fmol} \mathrm{ml}^{-1}$ only $20 \mathrm{~min}$ after a 10 -min i.v. delivery papaverine $\left(10 \mathrm{mg} \mathrm{kg} \mathrm{bw}^{-1}\right)$. Taken together these findings clearly show that papaverine-induced isovolemic hypotension is correlated with a prompt and massive renin-generated increase in plasma ANG II.

Our papaverine experiment has also shown that granule depletion may be induced only by an arterial pressure drop and is not dependent upon a decreased blood volume per se. As with hypovolemic hypotension the stimulus for granule release was not a change in plasma $\mathrm{Ca}, \mathrm{Mg}, \mathrm{Na}^{+}$, or $\mathrm{K}^{+}$or osmolal concentrations (Table 1) which were unchanged $120 \mathrm{~min}$ after the injection of the drug.

\subsection{CS response to acute blood withdrawal in an ancient and a modern fish}

Bowfins $(A$. calva $)$ are the most ancient extant species of fish known to possess CS (DeSmet, 1962; Garrett, 1942). Youson et al. (1976) showed that there are more than $300 \mathrm{CS}$ of variable sizes along the length of the bowfin kidneys representing an ancestral organization of CS. Withdrawal of $8 \mathrm{ml}$ blood $\mathrm{kg} \mathrm{bw}^{-1}$ from the bowfin caudal vein led to a $40 \%$ granule depletion (Figs. $4 \mathrm{c}$ and $\mathrm{d}$ and Table 2) within $120 \mathrm{~min}$. Even in this ancient holostean fish, the contents of the CS granules are released in response to a hypotension.

White suckers (C. commersoni) are neopterygian fishes, more highly evolved than $A$. rostrata, but they are still considered to be generalized rather than derivative teleosts. They possess two, relatively large CS; one found near the postero-dorsal surface of each kidney. Immunocytochemical and ultrastructural studies of these CS have identified principal cells, and a second, smaller population of cells having no immunoreactivity to stanniocalcin antibody (Marra et al., 1998). As in bowfins and eels, white sucker CS are responsive to hypotension/volume depletion as reflected in the marked decline of cytoplasmic granules in their principal cells following the withdrawal of $8 \mathrm{ml}$ blood $\mathrm{kg} \mathrm{bw}^{-1}$.
Our experiments have demonstrated a highly significant correlation between hypovolemic and isovolemic hypotension and the marked decline in number of what we believe are renin or isorenin-containing secretory granules (Butler and Zhang, 2001) from the CS in three divergent ray-finned fishes. However, there was no measurable change in plasma $\mathrm{Ca}$ concentrations in any of the three species examined so granule depletion was not $\mathrm{Ca}$-dependent. These results challenge the current theory that the CS granules contain primarily a calciumregulating hormone that is released only in response to hypercalcemia.

\section{Acknowledgments}

This work was supported from a Natural Sciences and Engineering Research Grant A-2359 to David G. Butler. Expert technical assistance was given by $\mathrm{Mr}$. Eric Lin who assisted Mr. Villadiego and M.Sc. student D.H. Zhang with most of the electron microscopy.

\section{References}

Bhattacharyya, T.K., Butler, D.G., Youson, J.H., 1982. Ultrastructure of the corpuscles of Stannius in the garpike (Lepisosteus platyrhynchus). Gen. Comp. Endocrinol. 46, 29-41.

Bernier, N.J., Kaiya, H., Takei, Y., Perry, S.F., 1999. Mediation of humoral catecholamine secretion by the renin-angiotensin system in hypotensive rainbow trout (Oncorhynchus mykiss). J. Endocrinol. 160, 351-363.

Butler, D.G., 1969. Corpuscles of Stannius and renal physiology in the eel (Anguilla rostrata). J. Fish. Res. Board Can. 26, 639-654.

Butler, D.G., 1993. Stanniectomy increases renal magnesium and calcium excretion in freshwater North American eels (Anguilla rostrata). J. Exp. Biol. 181, 107-118.

Butler, D.G., 1999. Osmoregulation in North American eels (Anguilla rostrata LeSueur) on land and in freshwater: effects of the corpuscles of Stannius. J. Comp. Physiol. B 169, 139-147.

Butler, D.G., Oudit, G.Y., 1994. Dorsal aortic and organ blood flow decrease following Stanniectomy in freshwater North American eels (Anguilla rostrata LeSueur). Comp. Biochem. Physiol. 108, 229-238.

Butler, D.G., Oudit, G.Y., 1995. Corpuscles of Stannius and blood flow regulation in freshwater North American eels, Anguilla rostrata LeSueur. J. Endocrinol. 145, 181-194.

Butler, D.G., Zhang, D.H., 2001. Corpuscles of Stannius secrete renin or an iso-renin that regulates cardiovascular function in freshwater North American eels, Anguilla rostrata LeSueur. Gen. Comp. Endocrinol. 124, 199-217.

Chan, D.K.O., Chester Jones, I., Henderson, I.W., Rankin, J.C., 1967. Studies on the experimental alteration of water and electrolyte composition of the eel (Anguilla anguilla L.). J. Endocrinol. 37, 297-317.

Chan, D.K.O., Rankin, J.C., Chester Jones, I., 1969. Influence of the adrenal cortex and the corpuscles of Stannius on osmoregulation in the European eel (Anguilla anguilla L.) adapted to freshwater. Gen. Comp. Endocrinol. Suppl. 2, 342-353.

Chester Jones, I., Henderson, I.W., Butler, D.G., 1965. Water and electrolyte flux in the European eel (Anguilla anguilla L.). Arch. Anat. Microsc. Morphol. Exp. 54, 453-469. 
Chester Jones, I., Henderson, I.W., Chan, D.K.O., Rankin, J.C., Mosley, W., Brown, J.J., Lever, A.F., Robertson, J.I.S., Tree, M., 1966. Pressor activity in extracts of the corpuscles of Stannius from the European eel (Anguilla anguilla L.). J. Endocrinol. 34, 339-408.

DeSmet, W., 1962. Considerations on the Stannius corpuscles and the interrenal tissue of bony fishes especially based on researches into Amia. Acta Zool. (Stockh.) 42, 201-219.

Fontaine, M., 1964. Corpuscles de Stannius et ŕegulation ionique (Ca, $\mathrm{K}, \mathrm{Na}$ ) du milieu interieur de l'Anguille (Anguilla anguilla L.). C. R. Hebd. Seances Acad. Sci. 259, 875-878.

Garrett, F.S., 1942. The development and phylogeny of the corpuscles of Stannius in ganoid and teleostean fishes. J. Morphol. 70, $41-67$.

Hirano, T., 1989. The corpuscles of Stannius. In: Pang, P.K.T., Schreibman, M.P. (Eds.), Vertebrate Endocrinology: Fundamentals and Biomedical Implications, vol. 3. Academic Press, San Diego, pp. 139-162.

Kenyon, C.J., Chester Jones, I., Dixon, R.N.B., 1980. Acute responses of the freshwater eel (Anguilla anguilla) to extracts of the corpuscles of Stannius opposing the effects of stanniosomatiectomy. Gen. Comp. Endocrinol. 41, 531-538.

Marra, L.E., Butler, D.G., Zhang, D.H., Oudit, G.Y., Youson, J.H., 1998. Corpuscles of Stannius and stanniocalcin-like immunoreactivity in the white sucker (Catastomus commersoni): evidence for a new cell type. Cell Tissue Res. 293, 155-164.

Marra, L.E., Youson, J.H., Butler, D.G., Friesen, H.G., Wagner, G.F., 1992. Stanniocalcin-like immunoreactivity in the corpuscles of Stannius of the bowfin Amia calva L.. Cell Tissue Res. 267, 283290.

Marra, L.E., Youson, J.H., Wendalaar Bonga, S.E., Hanssen, R.J.G.M., Wagner, G.F., 1994. Immunoreactivity of the corpuscles of Stannius of the garpike, Lepisosteus osseus L., to antisera against salmon and trout stanniocalcin. Cell Tissue Res. 277, 511518.
Ogawa, M., 1968. Osmotic and ionic regulation in goldfish following removal of the corpuscles of Stannius or the pituitary gland. Can. J. Zool. 46, 669-676.

Olson, K.R., Lipke, D.W., Kullman, D., Evan, A.P., Ryan, J.W., 1989. Localization of angiotensin-converting enzyme in the trout gill. J. Exp. Zool. 250, 109-115.

Oudit, G.Y., Butler, D.G., 1995. Angiotensin II and cardiovascular regulation in a freshwater teleost, Anguilla rostrata LeSueur. Am. J. Physiol. 269, R726-R735.

Sokabe, H., Nishimura, H., Ogawa, M., Oguri, M., 1970. Determination of renin in the corpuscles of Stannius of the teleost. Gen. Comp. Endocrinol. 14, 510-516.

Stannius, H., 1839. Uber Nebennieren bei Knochenfischen. Arch. Anat. Physiol. Wiss Med. 6, 97-101.

Takemoto, Y., Nakajima, T., Hasaegawa, Y., Watanabe, T.X., Kumagae, H., Sakakibara, S., 1983. Chemical structure of angiotensin formed by incubating plasma with the kidney and the corpuscles of Stannius in the chum salmon, Oncorhynchus keta. Gen. Comp. Endocrinol. 51, 219-227.

Tierney, M.L., Luke, G., Cramb, G., Hazon, N., 1995. The role of the renin-angiotensin system in the control of blood pressure and drinking in the European eel, Anguilla anguilla. Gen. Comp. Endocrinol. 100, 39-48.

Wagner, G.F., 1994. The molecular biology of the corpuscles of Stannius and regulation of stanniocalcin gene expression. In: Sherwood, N.W., Hew, C.L. (Eds.), Fish Physiology, vol. 13, Molecular Endocrinology of Fish. Academic Press, San Diego, pp. 273-306.

Youson, J.H., Butler, D.G., 1976. Fine structure of the adrenocortical homologue and the corpuscles of Stannius of Amia calva L.. Acta Zool. (Stockh.) 57, 212-238.

Youson, J.H., Butler, D.G., Chan, A.T.C., 1976. Identification and distribution of the adrenocortical homologue, chromaffin tissue, and corpuscles of Stannius in Amia calva L. Gen. Comp. Endocrinol. 29, 198-211. 